\title{
ローラ試験によるマイクロピッチングの実験的研究*
}

$$
\begin{array}{lllll}
\text { 吉 田信 義*1, 馬場 健 } 之^{* 2} \\
\text { 渡邊吉 弘*3, 潼 } \text { 晨 彦*4 }
\end{array}
$$

\section{Experimental Research of Micropitting by Roller Testing}

\author{
Nobuyoshi YOSHIDA*5, Takeshi BABA, \\ Yoshihiro WATANABE and Tokihiko TAKI \\ *5 Department of Mechanical Engineering, Okayama University of Science, \\ 1-1 Ridai-cho, Okayama-shi, Okayama, 700-0005 Japan
}

\begin{abstract}
Spalling and Scuffing are well known as the failure pattern of case-carburized gear. Micropitting was recently recognized as a failure too and already became a problem. Micropitting is very small failure on the contact surface. Despite of its size, it can lead, by accumulating, to several failures such as frosting or fatigue scuffing. In this study, the authors investigated the occurrence of micropitting and its tendency to increase in quantity. A disk machine with rolling and sliding was used. Fatigue tests were carried out with carburized SCM420 steel rollers and SCM420 steel rollers shot peened by two different methods; ultrasonic shot peening and air shot peening. Micropitting was generated by load around $1 / 4$ of the load that causes spalling. Quantity of micropitting increased as the number of cycles increased. Micropitting was observed in the faster test roller and its amount was less than the slower side. S-N curve was obtained from the fatigue life, which is assumed as the number of cycles in which the micropitting area reaches $5 \%$. As a result, the influence of the surface roughness seems to be large in the fatigue life of the micropitting.
\end{abstract}

Key Words: Gear, Micropitting, Pitting, Shot Peening, Fatigue Life

\section{1. 緒言}

歯車の面圧強度は, 歯面に浸炭や窒化といった表面 硬化処理を導入することにより，大幅に増大させるこ とに成功した ${ }^{(1-2)}$.これにより, ピッチングの問題は解 決し，代わってスポーリングやスカッフィングといっ た損傷形態が面圧強度の対象とされるようになった (34). しかし, Dudleyにより負荷繰返し数 $10^{10}$ を超して から歯の折損に至った報告がなされ，マイクロピッチ ングの存在が問題化するきっかけとなった ${ }^{(5)}$. その後, 歯車におけるマイクロピッチングの発生, フロスティ ングの観察などが精力的になされたの゙. しかし，現象 などの観察はされたものの，その設計面での対応はい まだ隹んではいない.

マイクロピッチングの焦点をぼかしているのは，歯 車の破壊に至る形態としてマイクロピッチング単独で はなく, フロスティング, スカッフィング, フレーキ ングといった別の形で表面化し，その後歯の折損に至

\footnotetext{
* 原稿受付 2006 年 9 月 4 日

*1 准員, 岡山理科大学大学院工学研究科(业 700-0005 岡山市 理大町 1-1)

*2 (株) 浅野歯車 (昰 589-0004 大阪狭山市東池尻 4-1402-1).

*3 東洋精鋼 (株) (画 490-1412 愛知県海部郡十四山村馬ヶ地 3195-1).

*4 正員, 岡山理科大学工学部.

E-mail : yoshida@mech.ous.ac.jp
}

って最終事象になるという複雑な変遷をたどることで ある ${ }^{(78)}$. そして設計的に嗉念される最大の問題点は, スポーリングやスカッフィングで期待される面圧強度 の半分以下といった低荷重域で往々にしてトラブルが 発生し()，その原因としてマイクロピッチングの関与 が否定できないことである.

こうしたマイクロピッチングそのものの性格はま だ不明な点が多い，そこで，面圧強度が高いとされて いる浸炭研削したローラ，ならびに更なる負荷容量增 加を目的として施工が試みられているショットピーニ ング処理を施したローラを用いて，マイクロピッチン グの発生ならびにその量の増加况について実験的に 明らがした。

\section{2. 試験片および試験方法}

$2 \cdot 1$ 試験口一ラ 試験ローラの形状は図 1 に 示寸ように外径 $60 \mathrm{~mm}$, 有效接触蝠 $5 \mathrm{~mm}$ の円筒で, 高 速側口ーラの接触面幅は $8 \mathrm{~mm}$ と広く取ってある. 材 質はクロムモリブデン鋼 SCM420 で，丸棒素材を旋削 加工後浸炭処理し，さらに旋削加工し，焼入れ焼戻し を行った. その後研削し，所定の形状に仕上げた.

またショットピーニングについてもその効果を把 握するために，代表的な従来型のエア一式ショットピ 


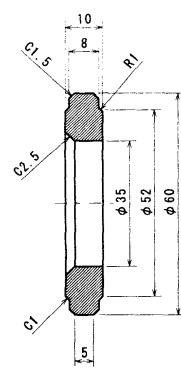

Slower Roller

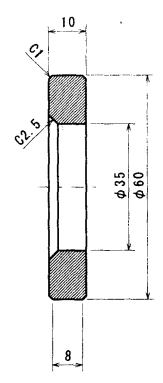

Faster Roller
Fig.1 Shapes and Dimensions of test rollers

Table1 Shot peening processing conditions

\begin{tabular}{|c|c|c|}
\hline $\begin{array}{c}\text { Shot peening } \\
\text { method }\end{array}$ & $\begin{array}{c}\text { Ultrasonic type } \\
\text { shot-peening unit }\end{array}$ & $\begin{array}{c}\text { Air type } \\
\text { shot-peening unit }\end{array}$ \\
\hline Abrasives & SUJ2 $\phi 0.82 \mathrm{~mm}$ & $\begin{array}{c}\text { RCW08PS } \\
\phi 0.81 \mathrm{~mm}\end{array}$ \\
\hline $\begin{array}{c}\text { Weight of } \\
\text { shot grain injections }\end{array}$ & $1.4 \mathrm{~g}$ & $4.75 \mathrm{~kg}$ \\
\hline Projection distance & $30 \mathrm{~mm}$ & $150 \mathrm{~mm}$ \\
\hline Sonotrode amplitude & $90 \mu \mathrm{m}$ & -- \\
\hline Projection pressure & -- & $0.25 \mathrm{MPa}$ \\
\hline $\begin{array}{c}\text { Revolutions per } \\
\text { minutes for work }\end{array}$ & $6 \mathrm{rpm}$ & $12 \mathrm{rpm}$ \\
\hline Blasting time & $360 \mathrm{sec}$ & $30 \mathrm{sec}$ \\
\hline
\end{tabular}

一ニングと超音波式ショットピーニングの 2 種類を採 用した. これらのショットピーニング処理は最終加工 の研削後に行い, その主要な処理条件を表 1 に示す. したがって, 面圧強度試験はショットピーニング末処 理試験片（以降 UNP と称する）, エア一式ショット ピーニング処理試験片（以降ASP と称する）, 超音波 式ショットピーニング処理試験片（以降 USP と称す る）の3 種類のローラ試験片について行う.

試験口ーラ接触面の表面粗さ $R_{z}$ の測定結果を図 2 に示す.測定条件は基淮長さ $0.25 \mathrm{~mm}$, 評価長さ $1.25 \mathrm{~mm}$ で，ローラの軸方向に測定した．眓には各仕上げ法に 全試験片の平均值とその標準偏差が示されており, ASP試験片の表面粗さが他の仕上げ法に比べて有意に 粗くなっている. なお, 試験ローラの接触面硬さは, ビッカース硬さにおいて UNP 試験片が 756HV, USP 試験片が 915HV，ASP 試験片が 884HV であった. ま た，試験片の残留応力の深さ方向への分布を図 3 に示 す. 残留応力の測定は，X線回折法を用いてローラの 円周方向に行い, 表面から内部二の応力分布は表面層 を電解研磨で除去しながら測定した.

$2 \cdot 2$ 試験譏と試験条件 試験は図 4 に示すば ね負荷式二円筒転功り滑り試験機で行った. 上下のロ 一ラ軸に取り付けられた 2 ローラと, それらローラ軸

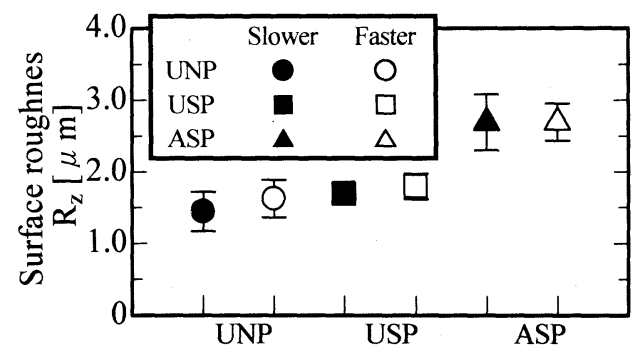

Fig.2 Measurements of surface roughness

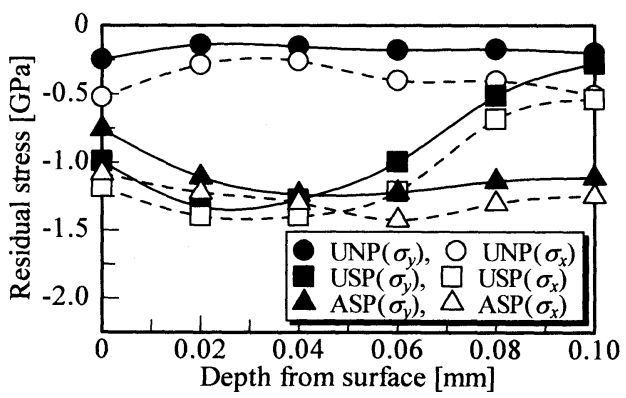

Fig.3 Residual stress distributions of test specimen

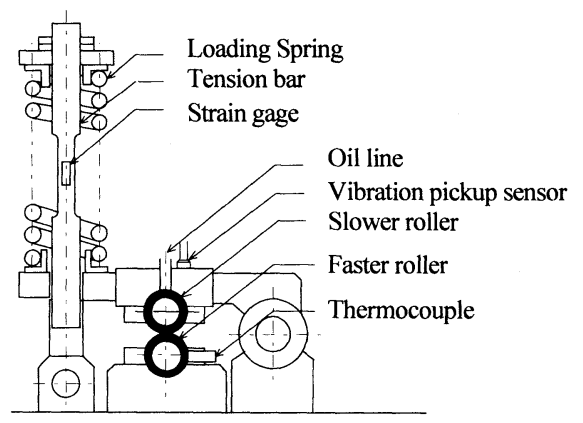

Fig.4 Schematic drawing of testing machine

の回転数を一定割合で変える歯車対とで動力循環方式 の形態を構成させ，そのサークルに $15 \mathrm{~kW}$ の可変モ一 タで動力を供給している. なお, モ一タと下側高速口 一ラ軸との間にトルク計を設置し, 動力循環中の損失 動力を測定し, 無負荷時と負荷時のトルク差から接触 ローラ間の摩擦力を算出している. 低速側の上側ロー ラ軸には下側ローラ軸の歯車を通して減速された回転 数で回転し，低速軸を支持しているレバーにばねによ り負荷をか外る.

潤滑油は極圧鉄道ギアオイル 3090 (粘度: $206.3 \mathrm{cSt}$, $311 \mathrm{~K}$ ）を, 給油温度 $318 \pm 5 \mathrm{~K}$, 給油量 $4.17 \mathrm{ml} / \mathrm{s}$ で真上 から強制給油した，試験中のローラ表面温度は，試験 片のしゅう動面に熱電対を押し付ける力法によって測 定した. 実験は高速側ローラ回転数 $1500 \mathrm{rpm}$, 低速側 ローラ回転数 $1291 \mathrm{rpm}$, 低速側ローラの滑り率ー $16.2 \%$ の一定速度で行い, 荷重はへルツ応力 $p_{m a x}=1.0 \mathrm{GPa}$ か 


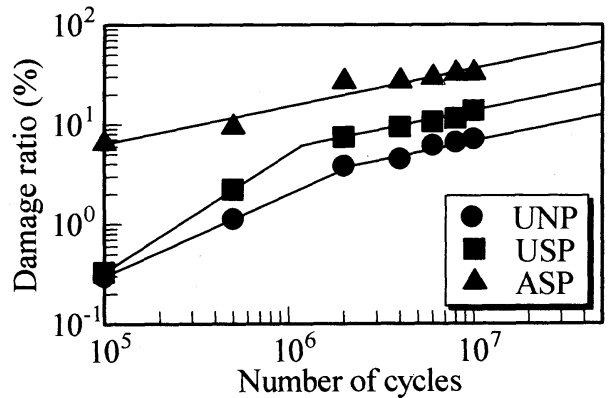

(a) Slower roller

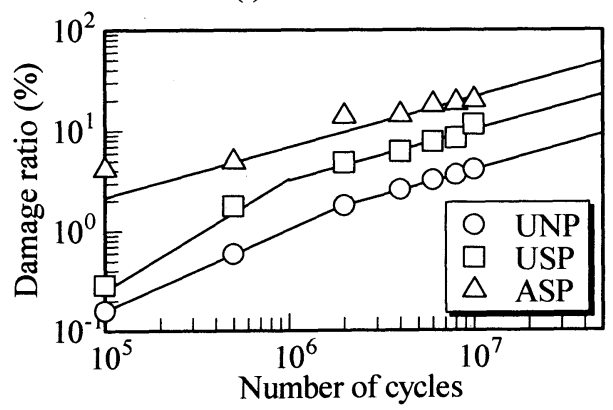

(b) Faster roller

Fig.5 Measurements of damage ratio $\left(p_{m a x}=2.0 \mathrm{GPa}\right)$

ら $2.0 \mathrm{GPa}$ の範囲で行った. 試験中は負荷繰返し数 $2.0 \times 10^{6}$ 回転ごとに試験機を停止し，しゅう動面の損傷 状况を観察, 記録した. なお, 滑り率は対象とする口 一ラ回転数と相手ローラ回転数の差を対象としている ローラ回転数の值て除して, 百分率表示したものであ る.

\section{3. 結果と考察}

3.1 試験口一ラの損僬状況 しゅう動面に発 生するマイクロピッチングはきわめて小さく, 肉眼で の観察が困難であり, 従来観察対象から除かれていた。 本試験ローラの面圧強度も, 従来はスポーリングやス カッフィングが対象となり, 20GPa 以上の面圧が議論 されてきた ${ }^{(910)}$. 本研究においても, 2.0GPa にてマイ クロピッチング以外の損傷が発生することはなかった。 しかしマイクロピッチングは, 接触荷重でその $1 / 4$, ヘ ルツ応力でその $1 / 2$ の $1.0 \mathrm{GPa}$ でも発生した.

マイクロピッチングは, 個々の面積がきわめて小さ い代わりにその発生個数はきわめて多い.これら接触 面に発生したマイクロピッチングの損傷量を求める手 段として, 従来のピッチンク試験でしばしば採用され ている,カーボンによる転写法を採用することとした. これは, マイクロピッチングの穴にカーボン粉末を埋 め込み，それをテープに転写し，写し取られたカーボ

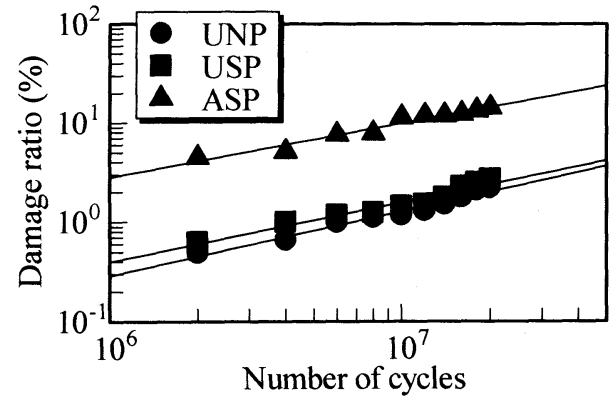

(a) Slower roller

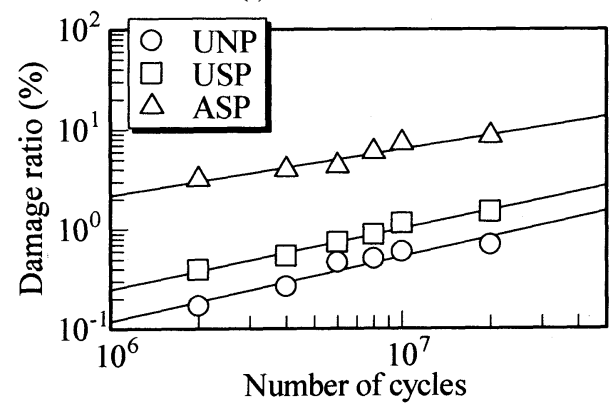

(b) Faster roller

Fig.6 Measurements of damage ratio $\left(p_{\max }=1.0 \mathrm{GPa}\right)$

ンを拡大して観察する方法で, 転写されたカーボンの 付着面積をパソコンの画像処理ソフトを用いて測定し た.この方法で測定した損傷面積が，しゅう動面の有 效接触面積に占める面積の割合を損傷率として定義し, マイクロピッチングの発生量の指標とした. また, こ の方法では接触面にカーボンを塗りつけた後, 脱脂綿 を用いてカーボンをふき取っており，こうすることで カーボンは損傷部分のみに残る. ショットピーニング 処理による圧痕にはカーボンは残らず，未試験状態の ローラの損傷率を測定した結果では，試験片の種類に よらず，損傷率は0\%であった。

圾験では, 運転中の潤滑状態を把握するために接触 面の損失動力を測定した．これより算出された摩察係 数はいずれの圾験でもほぼ $0.010 〜 0.015$ の範囲であり, 運転中の摩擦係数の経時変化，あるいは試験片の仕上 げ法や試験条件による顕著な違いは認められなかった。 ここで得られた摩擦係数は，この種の試験で一般的な 摩擦係数である $0.03 \sim 0.07$ に比べてかなり小さいもの となっているが，これは，接触面の損失動力を直接測 定しておらず，試験軸の軸受損失も含めた損失動力を 測定し，無負荷時の軸受損失を差し引いてもとめてお り,そこから来る誤差を含んでいるためと考えている.

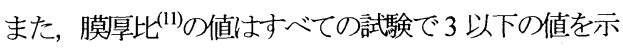
しており，一部の低負荷における試験を除くと，ほと 
んどの試験て膜厚比が 1 以下であることから, 潤滑状 態が混合潤滑，あるいは境界潤滑状態であることが分 かる. こうしたことを勘案しても，接触面の润滑状態 は良好で, 転がり疲労損傷の実験に好ましい状況にあ るといえる.

$3 \cdot 2$ 損鹪率の経時変化 マイクロピッチン グは個々の損傷が微細であるため, 単独で問題になる ことはまれであり, その発生量が多くなるにつれて歯 車の正常な運転を阻害する確率が高くなり, 問題視さ れるようになる. そこで, マイクロピッチングの発生 量の経時変化を追った.

マイクロピッチングの発生量の経時変化の一例とし て, 図 5 にヘルツ応力 $2.0 \mathrm{GPa}$ の場合を, 図6にヘルツ 応力 $1.0 \mathrm{GPa}$ の場合を示す. これらの図から, 次のよう な特街的現象が指摘できる. (1)損傷率は繰返し数と共 に増加している. 低荷重においても高荷重と同様な傾 向にあり, 繰返し数が増加しても新たな損傷発生量が 漸减するという，ピッチングにおけるなじみ現象はこ の範用でまだ認められない. (2)高速側ローラも低速側 ローラ同様に損傷し，ピッチングと際立った違いを見 せている.このことは歯車での実験でも確認されてい る(12). (3)ショットピーニング処理を施すことによる表 面状態の違いが損傷率の大小の差になって現れている. (4)高い接触圧の場合, 損傷率の増加傾向が途中で変化 する傾向にある. 損傷率が $3 \%$ を超す頃から，ショッ トピーニングの有無や種類にかかわらずほぼ一定の増 加傾向を示すが，それより損傷率の低い 運転初期の状 態では，試験片の種類によって増加傾向が一定になる までの差が見られる.これは，マイクロピッチングが 疲労現象であるため, 発生し始めるのに一定の時間を 要するためであると考えられる.こうした傾向は $1.6 \mathrm{GPa}$ 以上で明瞭に見られるが，それ以下の応力では 明暸ではなかった。

3.3 面圧強度 面圧強度は歯車など, その対 象物の使用限界強さを論ずるときに用いるものである. しかし，マイクロピッチングについてはこの点を論ず るまでに至っておらず，今後の課題となっている.こ の原因として主に2つのことが考えられる. 一いマ イクロピッチングが多発することに伴うフロスティン グとの関連で, その進行につれ変化する歯形変化に主 眼が置かれ，振動問題や動的荷重の増加と合わせて論 じられることになる，もう一つ小さいながらも亀裂 が確実に発生し, 応力集中の要因となりうることであ る. 歯車の歯は接触灾力のみならず曲げ応力も極めて 高く, 材料強度的には過酷な条件下に置力冰ている。 近年，歯車においてはフレーキングなどの表面損傷を

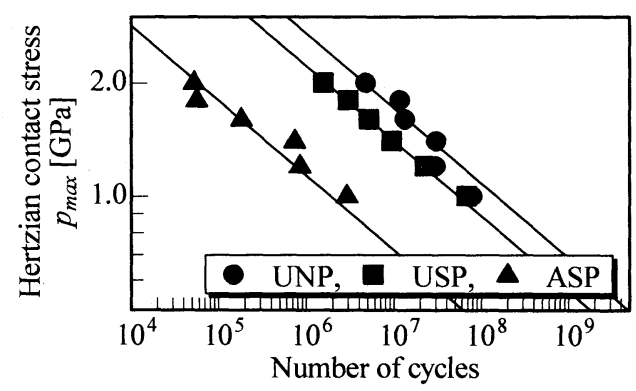

Fig. 7 Number of cycles at damage ratio reaches $5 \%$

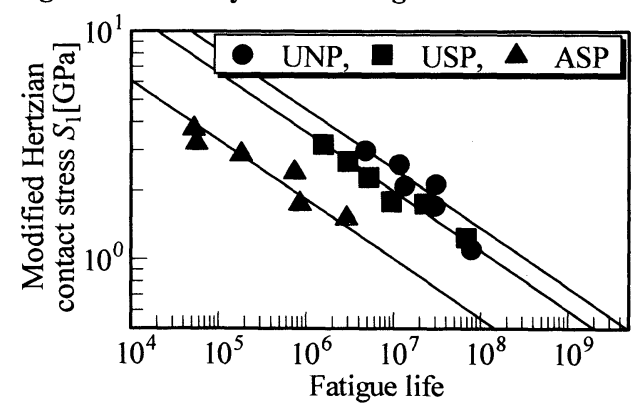

Fig.8 Relation between modified Hertzian contact stress and fatigue life

起点として歯の折損に至る事例が報告されており，こ のフレーキングの発生原因としてマイクロピッチング の存在が無視できない：こうした点を明らかにし，マ イクロピッチングの限界発生量を決定する必要がある.

こうした面圧強度を論ずる場合, マイクロピッチン グが綝返し数と共に単調に増加する性質をとらえ，い ずれの損傷形態にも適用できるよう，損傷率でまとめ ておくのが適当と考える. 寿命としての損傷率の限界 值は, 実験的に確認しやすく，ピッチングの場合でも 多く採用されている 1 10\%の範用が実用的と考えら れることから，本研究では中間の 5\%を採用する. ま た，寿命はその低い側のローラで規制されることから， 低速側ローラ試験片の寿命を取り上げる.

図 7 に応力一寿命曲線を示寸. 応力は試験へルツ応 力を用いた. 寿命は損傷率が 5\%に達したときの負荷 繰返し数とし，損傷率が 5\%に達しないで圾験を終了 したときは, 図5 あるいは図6のように試験の結果か ら得られた損傷率増加曲線から求めた. 3 種類の圾験 片の応力一寿命曲線は同じ勾配を示しているが，ASP 試験片の寿命方際立って低く, UNP 試験片とUSP 試 験片の寿命はほほ同じであることがわかる。これら， 試験片の種類による寿命の長短の関倸は, 試験片の表 面粗さの大小の関係とよく似ていることから, 表面粗 さの影響を考虑することを試みる. マイクロピッチン 


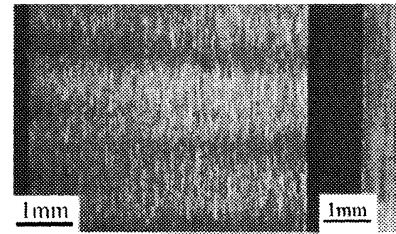

(a) Before test (b) After test

Fig.9 Observations of roller surface in UNP roller

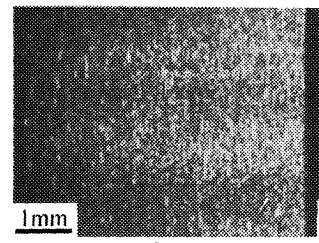

(a) Before test

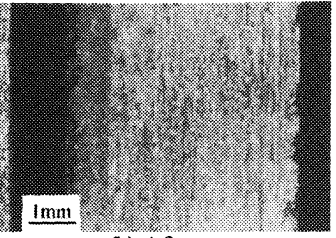

(b) After test

Fig.10 Observations of roller surface in USP roller

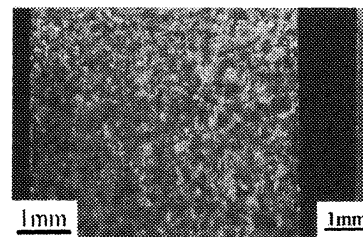

(a) Before test

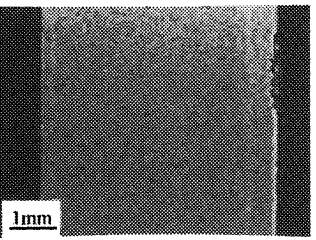

(b) After test

Fig.11Observations of roller surface in ASP roller

グに対する表面粗さの影響は定かではないが，ピッチ ングと類似しているものと仮定する. 歯車のピッチン グ強度における粗さの影響は(1)式(13)で表される.

$S_{1}=p_{\text {max }} \cdot D^{02}$

ここに, $S_{1}$ は修正応力, $D$ は接触する 2 面間の表面粗 さ $R_{z}$ の和を最小油膜㫗さ $h_{\text {mn }}$ で除した值である.なお, 表面粗さは文献(13)に従い，実験前の值である．最小 油膜㫗さ $h_{\text {man }}$ は Dowson-Higginson の式 $(14)$ から算出した。 最小油膜厚さの算出に用いた潤滑油粘度の值は, 試験 中に計測したローラ接触面温度から求めた. これより 求めた修正応力と $5 \%$ 損傷寿命の関係を図 8 に示寸. この結果, 3 種類の試験片の応力一寿命曲線はかなり 近づくが，まだ一致するに至らない，式(1)におけるD の指数 0.2 は，なじみ性のよい調質鋼製の歯車による 実験デー夕から求められたものであり，本実験で用い たなじみ性の低い浸炭鋼牲のローラの場合，運転によ るD值の低下が少ないため, $D$ の指数がもう少し大き い可能性がある. それにより 3 者のデー夕はさらに近 づくが，すべてを一致させることはできない：この違 いがショットピーニング処理によるもつである可能性 がある.

3.4 試験後ロ一ラの表面锶察 試験前後 の訌験片表面の光学顕微鏡写真を図 9 図 11 に示寸. 各図の(b)は試験の結果, マイクロピッチングの最も多

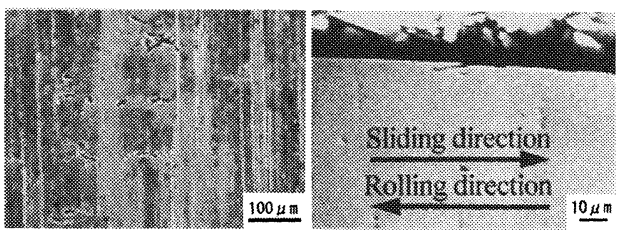
(a) Central part of roller
(b) Side view of sectioned roller

Fig.12 SEM micrograph of UNP slower roller
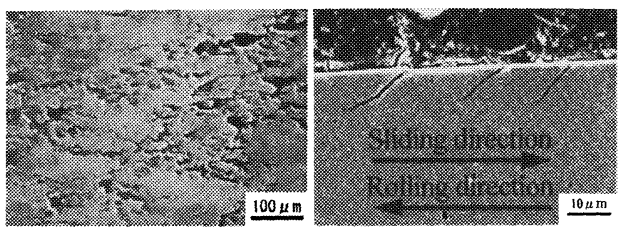

(a) Central part of roller

(b) Side view of sectioned roller

Fig.13 SEM micrograph of USP slower roller
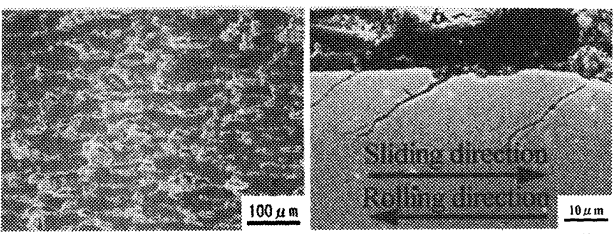

(a) Central part of roller (b) Side view of sectioned roller

Fig.14 SEM micrograph of ASP slower roller

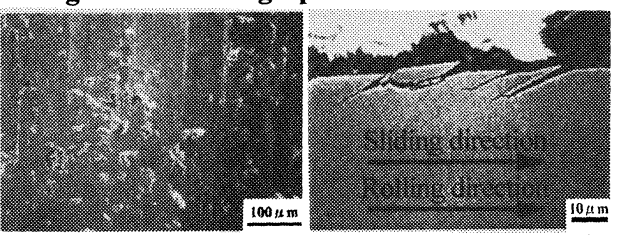

(a) Central part of roller (b) Side view of sectioned roller Fig.15 SEM micrograph of UNP faster roller

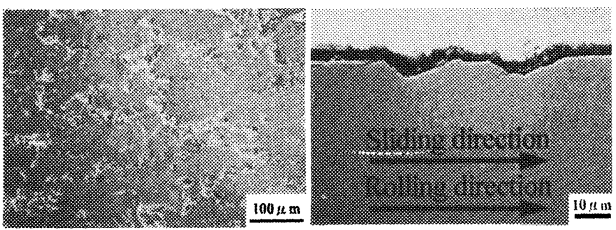

(a) Central part of roller (b) Side view of sectioned roller

Fig.16 SEM micrograph of USP faster roller
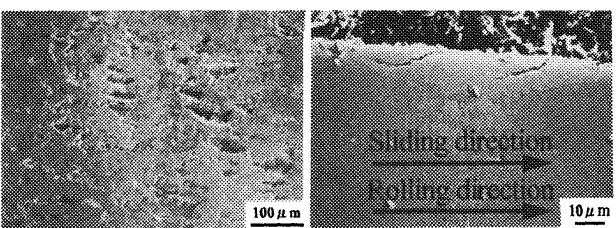

(a) Central part of roller

(b) Side view of sectioned roller

Fig.17 SEM micrograph of ASP faster roller

く発生したヘルツ応力 $2.0 \mathrm{GPa}$ において繰り返し数 1.0x10 回経過時の低速側ローラで, (a) はその試験前 の状態である. 試験後の表面はおびただしいマイクロ ピッチングの発生のため, 運妘前の状態で確認できる 


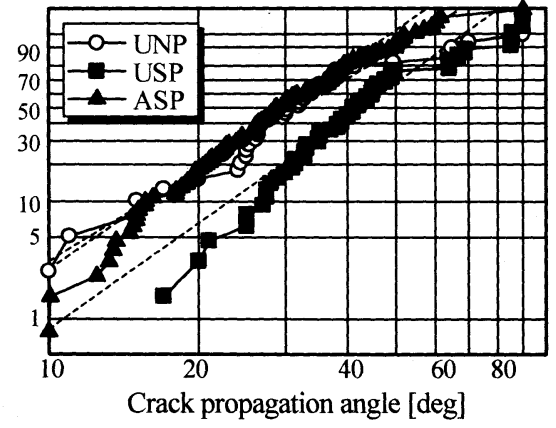

Fig.18 Weibull plot of crack propagation angle

金属光沢が見られず,表面が荒れた感じとなっている. 特に接触面端部が一様にがけ崩れのように浅く脱落し ている.

ローラ中央部のマイクロピッチングの SEM による 観察結果を低速側ローラについて図 12〜図 14 に, 高 速側ローラについて図 15〜図 17 に示寸. 各図の(a)に 接触面中央部の表面観察写真を，(b)は接触面中央部を 円周方向に切断し，断面観察を行った結果を示す. 観 察試料揭 9 図 11 と同様, ヘルツ応力 $2.0 \mathrm{GPa}$ て試 験を行ったものである. なお, ローラの転がり方向は， (a)の場合は下から上に向かっており，(b)の場合は図中 に示してある.

低速側，高速側ともに(a)の圾験片中央部ではマイク ロピッチングが発生している. (b)の断面写真では低速 側，高速側とも亀裂の発生が確認できる. 亀裂は接触 面加発生し内部一と進展しており, 進展方向は低速 側試験片では転がり方向，高速側試験片では反転がり 方向であった. これより, 表面から発生した亀裂が進 展し, 表面が剥離したことでマイクロピッチングが発 生したものと考えられる.

マイクロピッチングは，接触する 2 面間の表面粗さ の突起部同士が接触寸る際に発生寸る高い摩擦係数の ため, 通常接触面下に存在する最大せん断応力が接触 面に移動し，その応力值も高いため, 亀裂の発生に至 ると考えられる. これより表面粗さの突起部に発生し た刍裂がその突起の頂部が終わる欲部で表面に抜けて ピットを完成させる.これよりマイクロピッチングは ピッチングにおける亀裂准展に必要な S. Way の油進 入説 ${ }^{(15)}$ に重点を置かなくとも説明できるが，これは油 進入説を否定するものではなく, 図 5, 図 6 て観察さ れるように，低速側のほうが高速側よりも多くマイク ロピッチングが発生するのは油進入効果の現れである と考える.

マイクロピッチングの発生機構を考える場合, 亀裂
の進入方向は重要な情報となる. 図 12〜図 17 で見ら れるように，亀裂の進入方向と接触面とのな寸角度は 必ずしも一致していない，そこで, ヘルツ㐫力 $2.0 \mathrm{GPa}$ で試験した低速側ローラ試験片に発生した，亀裂の進 入角度を調べた. 測定はローラ幅中央部の任意の位置 で円周方向に圾験片を切断し， 円周長さ $19 \mathrm{~mm}$ の間に 発生したすべての亀裂てついて行った. 図18 はそうし た測定データをワイブル確摔紙にプロットしたもので ある. この結果, ASP およびUNP の 2 つの圾験片は ほほ同じ角度分布であるのに対し, USP 試験片は約 10 度程度大きな角度を示している. なお，図で注目され ることは, 亀裂の進入角度が 10 度から 90 度まて幅広 く観察されていることである.このことは，ピッチン ク試験で20〜40度と指摘されているデータ(16-1) と大き な違いを見せている，各圾験片における角度分布の平 均值は，UNP 試験片が 35 度，USP 試験片が 45 度， ASP 圾験片が 31 度であった.

\section{4. 結言}

歯車のマイクロピッチングを設計にどう取り込むか を主眼に，ローラ試験機を用いて調べた，その結果以 下のことがわかった。

(1) マイクロピッチングは従来問題とされていたス ポーリング損傷を発生させる荷重の $1 / 4$ 程度の低 荷重でも発生する.

（2）マイクロピッチングの発生量は, 負荷繰返し数に 比例して増加する。

（3）損傷率 5\%を寿命としたときの応力一寿命曲線を 求めることが出来た. ショットピーニングの効果 を見ると，表面粗さが大きいASP 試験片が他の2 種類の試験片に比べて短寿命であり，ショットピ 一ニングによる残留応力の変化などよりも表面 粗さの影響が大きいように思われる。

(4) 高速側ローラにもマイクロピッチングが発生し, その発生量は低速側ローラよりも幾分少なくな っていた.この結果は，歯車で見られる現象と一 致している。

（5）ローラ試験片に発生した亀裂の進展角度を測定 した結果，亀裂の分布は 10〜90 度の範用を示し た.これは，類以の損傷であるピッチングと大き く異なる特徴である.

\section{文献}

(1) Yoshida, M. et al, A Study on the Pitting Fatigue Strength of Carburized Gears, Transactions of the Society of Automotive Engineers of Japan, Vol.27, No.2, April 1996, pp.125-130. 
(2) Abe, S. and Ikeda, M., High Pitting Strength Steels based on Super-carburizing, Kobe Steel Engineering Reports, Vol.54, No.3, Dec. 2004, pp.21-24.

(3) Fujita, K. et al., The Surface Durability of the Case -Hardened Ni-Cr Steel and Its Optimum case depth in Japanese, Transactions of the Japan Society of Mechanical Engineers, Vol.42, No.358 (1976), pp.1916-1924.

(4) Yoshida, A., Effect of Specific Sliding on Surface Durability of Case-Hardened Chromium-Molybdenum Steel Roller, Bulletin of the JSME, Vol.23, No.178 (1980), pp.595-602.

(5) Dudley, D.W., Gear Wear, in Wear Control Handbook, The American Society of Mechanical Engineering, New York (1980), pp.755-830.

(6) Taki, T., Study on the wear phenomena in the case-carburized gear surface, Journal of Japanese Society of Tribologists, Vol.25, No.9(1980), pp.632-636.

(7) MacPherson, P.B. and Cameron, A., Fatigue Scoring A New Form of Lubricant Failure, ASLE Transactions, Vol.16, No.1 (1973)

(8) The Japan Society of Mechanical Engineers ed., Gear Failure -A Pictorial Guide- (2006), The Japan Society of Mechanical Engineers, pp.155-210.

(9) Takeuchi, T. et al., Surface Durability of CaseCarburized Gears (Influence of Hardening Profile on Change of Rolling-Sliding Contact Surface), Transactions of the Japan Society of Mechanical Engineers, Series C, Vol.70, No.697 (2004), pp.2774-2779.
(10) Haizuka, S. et al., Studies of Tooth Surface Strength and Wear of Case Hardened Spur Gears (Influence of Tooth Forms, Circumferential Velocities and Surface Treatments), Transactions of the Japan Society of Mechanical Engineers, Series C, Vol.68, No.667 (2002), pp.941-948.

(11) Tallian, T.E., On Competing Failure Modes in Rolling Contacts, ASLE Transactions, Vol.10, No.4 (1967), pp.418-439.

(12) Ariura, A. et al., Load-Carrying Capacities of Case- Hardened Gears (Gray-Staining on the Tooth Surface of Carburized Gears), Journal of Japanese Society of Tribologists, Vol.24, No.10 (1979), pp.662-669.

(13) Taki, T., Effect of gear material and hardness on pitting durability in Japanese, Transactions of the Japan Society of Mechanical Engineers, Series C, Vol.52, No.474 (1986), pp.542-548.

(14) Dowson, D. and Higginson, G.R., Elasto-hydodynamic Lubrication, Pergamon Press, (1966).

(15) Way, S., Pitting due to rolling contact, J. App. Mech., Vol.2 (1935), pp.A49-A58.

(16) Fujita, K. et al., A Study on the Effect of Roller Width on Pitting of Thermally Refined Roller, Journal of Japanese Society of Tribologists, Vol.29, No.7 (1984), pp.515-521.

(17) Miyoshi, H., Study on Pitting in Rolling Sliding Contact (1), Journal of Japanese Society of Tribologists, Vol.20, No.12 (1975), pp.843-851. 